\title{
Imla' Learning Media by Using Youtube for Prospective Students at Gontor Islamic Boarding School Darussalam
}

\author{
Laili Mas Ulliyah Hasan ${ }^{1}$ * ${ }^{*}$ mi Machmudah ${ }^{2}$ \\ 1,2 Universitas Islam Negeri Maulana Malik Ibrahim Malang, Indonesia \\ "Corresponding Author. Email: chalely01@gmail.com
}

\begin{abstract}
Along with developing an all-digital era, learning media also adapts to the situation. YouTube is currently a growing trend in society. This social media if appropriately packaged can also be an exciting learning media and provide a plus. The purpose of this research are: 1) To describe how the imla' learning process uses youtube as a medium for prospective students of Gontor. (2) Describe how effective the use of IMLA' by using YouTube is for prospective students of Gontor. The reason for choosing this title is because there is no learning media that supports Arabic learning for Imla' to prospective students of Gontor that can be reached from all over in Indonesia. Researchers used experimental researchers analyzed quantitative data from the results of the youtube experiment, which was tested by statistical methods (Static Analysis). The method used to analyze the data is the symbol t-test. After going through the t-test, the result of the t-count is $3.368 \%$, the result is greater than the ttable. Based on these results, the researcher's hypothesis (Ha) is accepted because $\mathrm{Ha}$ is accepted so that the research results are effective.
\end{abstract}

Keywords: Imla', Youtube

\section{INTRODUCTION}

There are many rapid developments in all aspects of human activity in this digital era. The influence of this all-digital era makes all experts have to turn to technology. Starting from the economy, society to education [1]. In the field of education, all education activists inevitably have to keep up with this sophisticated era. Educational activists who still stutter in technology matters must pursue targets to master it. If you are still struggling in an entirely manual era, it will negatively impact. They will be marginalized and thrown into the competitive wave of globalization [2].

The most frequently accessed video-based social media on smartphones is Youtube. Everything is on Youtube, starting from news, latest music clips, comedy, etc. The Youtube site provides various information in videos, including audio. Youtube is intended for those who want to find information in videos. Apart from searching for videos, visitors can also upload their videos to Youtube and share them worldwide [3].

YouTube is a popular video-sharing site where users can upload, watch and share videos in a certain way for free. YouTube is used by more than a billion people, nearly a third of all internet users. These users watch billions of hours of video every day and generate billions of views [4]. YouTube False: There is only one medium being developed now, and viewers are asking for it because everyone can download videos for free and with no time limit on YouTube. In terms of information, this social media makes the audience get information in it [5].

Not only on the internet but also in print media, one of which is in textbooks. In the current era of technology, textbooks can focus on print and must keep up with the times to continue to exist [6]. In the face of many competitors in the textbook industry, specific strategies are needed: using social media on YouTube to convert their textbooks. 
In preparing props for their work, the teacher must determine the use of technology today, especially for YouTube, to be selective and apply it in learning Arabic. For example, depending on the video application used or delivered in the teaching and learning process on YouTube [7]. Therefore, the use of technology with YouTube as an alternative to learn must be developed according to the characteristics of the subjects being taught. So that the learning process is more effective and efficient, involving students actively during the teaching and learning process and making it seem fun with current technological developments [8].

In the learning process at universities, many lecturers recommend students, especially in the Arabic Language Education study program [9], to use YouTube social media as a learning medium and even as a learning final project material and a form of formative evaluation. Therefore, it is beneficial to improve the abilities of prospective students of Gontor and hone their skills in imla' wherever and whenever [10].

Based on the researcher's interview on YouTube with one of the students of the preparatory program at the Dar es Salaam Kontour Institute. The researcher's interview with the students for the preparatory program on YouTube shows that most of the students for the preparatory program at the Institute of Dar es Salaam Kontour feel difficulty teaching the writing skill, especially in writing the correct word or sentence [11]. Therefore, some problems exist when teaching the Arabic language, especially teaching the skill of writing in dictation. In addition, many prep students cannot write because they feel it is challenging to write the correct vocabulary before the prep students are able to understand the meaning of all the vocabulary.

In preparing the teaching aids for his work, the teacher must determine the use of technology in this day and age, especially for YouTube, to be selective and apply it in learning the Arabic language. It depends on the video application used or submitted in teaching and learning on YouTube [12].

With the problems that exist in writing skills, especially in writing dictation, this learning looks pretty monotonous, so the author here wants to facilitate prospective students of Gontor by using the largest media that is overgrowing at the time, namely YouTube. It is challenging to separate millennials from those I understand are smart today. YouTube is very popular for millennial-sized children in the 4.0 development era, so studying YouTube about its good writing will make prospective students learn more from each other and know how to write pictures. Engaging animations and videos without a minimum duration to maximize teachers in providing clear dictation education.

Based on these desired goals, this research needs to be done. Therefore, this present study tries to measure the teaching of dictation using YouTube for prospective students of Gontor.

\section{METHOD}

The approach used in this study is a quantitative approach used to determine the effectiveness of using youtube for imla' learning to prospective students of Gontor with this type of experimental research [13]. Quantitative research is a process of finding knowledge that uses data in the form of numbers as a tool to analyze information about what you want to know [14].

The population in this study were all prospective students of Gontor where now everyone is familiar with the use of smartphones. Because the population is very large or exceeds 1000 , it is impossible for the entire object of the study to be taken so that the sample is purposive sampling. The samples taken were divided into Class B as an experimental class with 35 prospective students and Class A as a control class with 35 prospective students.

Meanwhile, the tests given to students are in the form of pre-test and post-test with the scope of Arabic dictation/imla' ability to enter Gontor.

In this study, researchers analyzed quantitative data from the experimental results of youtube production which were tested by statistical methods (Static Analysis) [15]. The method used to analyze the data is the symbol t-statistics. The following:

$$
\mathrm{t}=\sqrt{\sqrt{\left(\frac{\sum x^{2}+\Sigma \mathrm{y}^{2}}{N x+N \mathrm{y}-2}\right)\left(\frac{1}{N x}+\frac{1}{N y}\right)}}
$$

$\mathrm{Mx}=$ is the modified scale from the experimental group

My = scale adjusted from the control group

$\Sigma \times 2=$ the sum of the number of squared deviations from the results of the experimental group

$\Sigma y 2=$ the sum of the number of squared deviations from the results of the control group

$\mathrm{Nx}=$ the number of students in the experimental group

$\mathrm{Ny}=$ the number of students in the control group 


\section{RESULT AND DISCUSSION}

\subsection{The Imla' Learning Process using Youtube for Prospective Students of Gontor}

The researcher started the imla' teaching process in a particular class for prospective students of Gontor from 3 February 2020 AD to 7 March 2020, to teach spelling using YouTube. Before teaching imla' on YouTube, the researcher analyzed the needs by displaying the data obtained by observation on the YouTube tracker. These are the needs and problems in imla' teaching facilities using youtube. Researchers conducted observations with YouTube followers at Chalely Official. He interviewed a researcher named Muhammad Fernanda as a prospective student of Gontor about his opinion on teaching Islamic teachings (Interview result).

Students are challenging to teach and understand imla', although there is no easy way to understand them in learning. And when the exam is in Gontor, imla' is an essential lesson for the success of Gontor students. It is chaos for all prospective students of Gontor. From here, the researcher discusses that the problem of prospective students of Gontor is fragile in writing imla' dictation, because they do not know what imla' is, write the correct alphabet and network to answer the dictation exam in Gontor.

The first meeting, Researchers held the first meeting on Sunday, February 2nd, 2020, for prospective students of Gontor. The time he does is from seven to nine (07:00 - 09.00) in the morning. After providing information to the students for the preparatory program about the purpose of this research, I started a pre-test to determine their ability to teach imla' before using the YouTube application. The pre-test was given a text about imla' related to the test subject to enter Gontor. And how is the pretest, the researcher forms students for the preparation program for watching youtube channel official. After the test is complete, the researcher gives time for students to improve their writing for 5 minutes, then collects the answer sheet in the WhatsApp group and the researcher evaluates it directly.

The second meeting, the researcher held a second meeting on Saturday, February 15th, 2020. Again, prospective students of Gontor are asked to watch YouTube for dictation on writing the letters of the alphabet and letters. After the youtube video ended, the researcher gave 5 minutes to correct his writing, then collected the answer sheet in the WhatsApp group, and the researcher did a direct evaluation. Then a complete explanation and students take notes on an excellent note preparation program in the WhatsApp group.

The researcher continued with slow teaching until the students reached an understanding. Then, after paying attention to the students about the statements and explanations presented by the researcher, he allowed them to ask questions about what they did not understand and then answer. So, to the end of the text, repeated once. Then the researcher closed this meeting with prayers and greetings.

The third meeting, The researcher held this third meeting on Sunday, February 16th, 2020. The researcher taught imla' material about writing alphabetic connections. After the youtube video ended, the researcher gave 5 minutes to correct the writing, then collected the answer sheet in the WhatsApp group, and the researcher did a direct evaluation. Then complete explanations, and students take notes on an excellent note preparation program. The researcher continued with slow teaching until the students reached an understanding. After paying attention to the students about the statements and explanations presented by the researcher, he allowed them to ask questions about what they did not understand and then answer.

Fourth meeting, The researcher held this second meeting on Saturday, February 22th, 2020 AD. The researcher taught the material on the imla 'writing of Sukun, Dhamma, and the relationship of words, AlQomariyah and Asy-Syamsiyah After the youtube video ended, the researcher gave 5 minutes to correct the writing, then collected the answer sheet in the WhatsApp group, and the researcher did a direct evaluation. Then complete explanations and notes for students of good note preparation program on WhatsApp.

The researcher continued with slow teaching until the students reached an understanding. Then, after paying attention to the students about the statements and explanations presented by the researcher, he allowed them to ask questions about what they did not understand and then answer. So, to the end of the text, repeated once. Then the researcher closed this meeting with prayers and greetings.

Fifth meeting, The researcher held this third meeting on Sunday, February 23rd, 2020. The researcher explained today's educational process to students for the preparation program; then, I started watching YouTube for dictation about the exam simulation.

After the youtube video ended, the researcher gave 5 minutes to correct the writing, then collected 
the answer sheet in the WhatsApp group, and the researcher did a direct evaluation. Then a complete explanation and collect the answers in the WhatsApp group. After that, the researcher continued with slow teaching until the students understood. Then, after paying attention to the students about the statements and explanations presented by the researcher, he allowed them to ask questions about what they did not understand and then answer.

Sixth meeting, The researcher held this second meeting on Saturday, February 29th, 2020. The researcher taught the imla' about the exam simulation. After the youtube video ended, the researcher gave 5 minutes to correct the writing, then collected the answer sheet in the WhatsApp group, and the researcher did a direct evaluation. Then a complete explanation and students take notes on an excellent note preparation program in the WhatsApp group.

The researcher continued with slow teaching until the students reached an understanding. Then, after paying attention to the students about the statements and explanations presented by the researcher, he allowed them to ask questions about what they did not understand and then answer. So, to the end of the text, repeated once. Then the researcher closed this meeting with prayers and greetings.

Seventh meeting, The researcher held this third meeting on Sunday, March 1st, 2020 M. The researcher taught imla' about exam simulations on youtube. After the youtube video ended, the researcher gave 5 minutes to correct the writing, then collected the answer sheet in the WhatsApp group, and the researcher did a direct evaluation. Then a complete explanation and students take notes on an excellent note preparation program on WhatsApp. The researcher continued with slow teaching until the students reached an understanding. Then, after paying attention to the students about the statements and explanations presented by the researcher, he allowed them to ask questions about what they did not understand and then answer.

The eighth meeting, The researcher held this meeting on Saturday, March 7th, 2020; precisely for this meeting, the researcher used this opportunity to do a post-test for prospective students of Gontor. The post-test was to determine their ability to write IMLA' after using the YouTube application. The test was carried out by providing text about IMLA' related to the test subject to enter Gontor. And how was the post-test formed by the researcher for the preparation program students in preparation for watching YouTube. After the test ended, the researcher gave 5 minutes to correct his writing, then collected the answer sheet in the WhatsApp group, and the researcher evaluated it directly.

\subsection{Effectiveness of using Youtube for Imla' to Prospective Student Gontor}

When the Imla's learning process using Youtube was completed, the researchers conducted a trial. In this study, an experimental model was used so that a control class was needed, namely the Capel A class with 35 prospective students. The researcher entered this class only two times for pre-test and post-test. Researchers used tests to measure students' ability to master Islamic teachings before and after using youtube for the experimental class. At the same time, the control class is used to measure the ability of prospective students before and after the teacher explains. So that in the end, the researcher will compare the results in the experimental class with the control class.

Before doing the calculations, the researcher determines the research hypothesis, namely:

$\mathrm{H}_{0}=$ There is no effect of using pre and post YouTube media usage for Imla' learning.

$\mathrm{H}_{\mathrm{a}}=$ There is an effect of using the youtube media for imla by prospective student Gontor.

The basis for making T-test decisions are as follows:

If $\mathrm{T}$ count $>\mathrm{T}$ table $=\mathrm{H}_{0}$ is rejected and $\mathrm{Ha}$ is accepted

If $\mathrm{T}$ count $<\mathrm{T}$ table $=\mathrm{H}_{0}$ is accepted and $\mathrm{Ha}$ is rejected

$$
\begin{array}{cc}
\text { T.S } \mathrm{S}_{0,01}= & 2,3825 \\
\text { T.So,o5 } & =1,6676
\end{array}
$$

\section{$1,6676<2,3825<3,368$}

From the previous table, the researcher found that the $t$-statistical result $=3.368$. Based on this result, the researcher set the t-table that the result in the freedom list (degree of freedom) from the t-table is that the moral result is $1 \%=2.3825$, and the result in the moral estimate is $5 \%=1.6676$.

The result of the decision is based on:

T-test

T.test (calculation $\mathrm{t}) \mathrm{t}$. table $<(\mathrm{t}$ table $)=$ got experimental $=$ acceptable 
T.test $($ calculation $\mathrm{t})$ t.table $>(\mathrm{t}$ table $)=$ test failed $=$ unacceptable

The statistic result $=3.368$ and this result is greater than the result of the moral assessment $1 \%=$ 2.3825 and the result of the moral assessment $5 \%=$ 1.6676 , meaning that this is acceptable.

It can be concluded then $\mathrm{HO}$ is rejected and $\mathrm{Ha}$ is accepted. So it is clear that there is an effect of using YouTube for imla' learning for prospective student Darussalam Gontor.

\section{CONCLUSION}

The researcher started the imla learning process in a particular class for prospective students of Gontor from 3 February 2020 AD to 7 March 2020, for imla learning using YouTube. First meeting Researchers held the first meeting on Sunday, February 2nd, 2020. The second meeting, for the imla' of writing the letters of the alphabet and the movement of the alphabet. The third meeting, about writing alphabetical connections. The fourth meeting, about the writing of breadfruit, dhomma, and word relations, Al-Qomariyah \& Asy-Syamsiyah. The fifth meeting, about the exam simulation. The sixth meeting, for imla 'practice about the exam simulation. The seventh meeting, for the dictation of the exam simulation. Finally, the eighth meeting, and specifically for this meeting, the researcher used this opportunity to do a post-test for prospective students.

Based on data analysis that has been researched carefully. The researcher found that the result of tstatistic $=3,368$ and the degree of freedom was 68 , then searched the page as the result of the t-table and found that the result $=1.6676,5 \%$ moral level, and 2.3825 at $1 \%$ moral level. And because of the census results. 3,368 is greater than the result at the 5\% moral level, or the $1 \%$ moral level. It means that Ho is rejected and $\mathrm{Ha}$ is accepted, meaning that the research hypothesis is accepted. The conclusion is that this is acceptable. It shows an increase in results and comparisons between classes that do not use YouTube to learn Imla' and practical classes that use YouTube, this means that the use of YouTube for IMLA learning has been effective.

\section{REFERENCES}

[1] J. A. DeCesare, User Uploads and YouTube One Channels for Teaching, Learning, and Research. Library Technology Reports. 2014.
[2] Haniah, "Pemanfaatan Teknologi Informasi Dalam Mengatasi Masalah Belajar Bahasa Arab 2014." Al-Ta'rib, 2, 2014.

[3] A. Muhaemin, 5 Situs yang Paling Banyak Dikunjungi. [Online]. 2017. Pikiran Rakyat. Available from:

http://www.pikiranrakyat.com/hidup gaya/2017/10/20/5-situsyang-paling-banyak dikunjungi-411970 [Accessed: 4 April 2018] (2017).

[4] F. Faiqoh. "Youtube Sebagai Sarana Komunikasi Bagi Komunitas Vidgram”. Jurnal Komunikasi Kareba, 5(2) (2016).

[5] G. L. Ă. Z. Ă. Roiu, New media versus news media, 3. 2008.

[6] A. P. Patmaningrum., D. Ayu, "Pengaruh Youtube Di Smartphone Terhadap Perkembangan Komunikasi Interpersonal Anak". Jurnal Penelitian Komunikasi, 21(2) (2018).

[7] Kuswoyo, "Kebutuhan Media Daring Untuk Pembelajaran Bahasa Arab.” El-Wahdah: Jurnal Pendidikan, 1 (1) (2020), 29-44.

[8] Muthmainnah, and A. Annas, "Pemanfaatan 'Vlog' Sebagai Media Pembelajaran Dalam Meningkatkan Maharah Kalam Bagi Mahasiswa IAIN Kudus." Arabia 12 (2) (2020) 123. https://doi.org/10.21043/arabia.v12i2.8073.

[9] Munir, Kurikulum Berbasis Teknologi Informasi dan Komunikasi, Bandung: Alfabeta, 2010.

[10] A. Wahyudi, Indonesia, Raksasa Teknologi Digital Asia. [Online]. 2017. Katadata.co.id. Available from: https://katadata.co.id/opini/2015/09/29/indonesia raksasa-teknologi-digital-asia

[11] A. Adiluhung, wawancara tanggal 7 bulan February tahun 2020, "wawancara tentang kesulitan dalam keterampilan menulis", Calon Santri/Santriwati Gontor.

[12] U. S. Sa'ud, Inovasi Pendidikan. Bandung: Alfabeta, 2009.

[13] T. T. Mustafidah, Hidayati, Penelitian Kuantitatif (Sebuah Pengantar). Bandung: Alfabeta, 2014

[14] S. Arikunto, Prosedur Penelitian Suatu Pendekatan Praktek. Jakarta: PT Rineka Cipta, 2002.

[15] Sugiyono, Metode Penelitian Kuantitatif, Kualitatif, dan R \& D. Bandung: Alfabeta, 2014. 